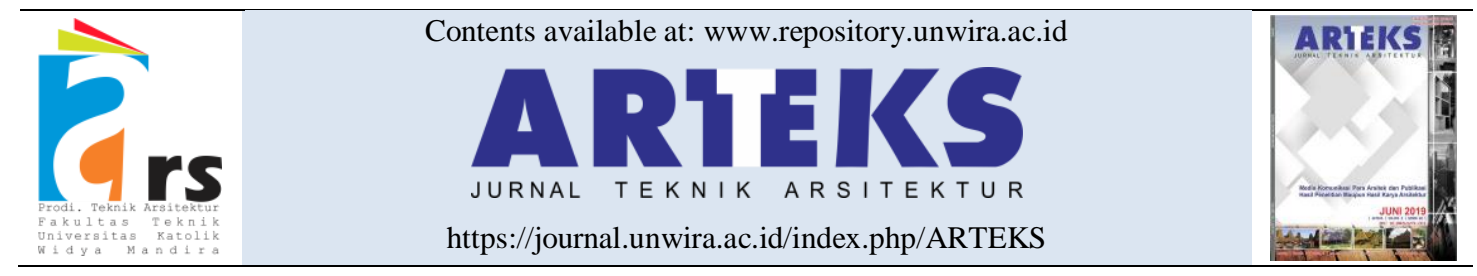

Research paper

doi: $10.30822 /$ arteks.v5i3.564

\title{
The utilization of paving blocks as environmental heat reduction materials
}

\author{
Mohammad Imran ${ }^{*}$ (D), Novita Shamin², Rahmi Budi As'Adiyah ${ }^{3}$ \\ ${ }^{1,2}$ Department of Architecture Engineering, STITEK Bina Taruna \\ Jl. Jaksa Agung Soeprapto, no. 40, Gorontalo City - 96115, Indonesia \\ ${ }^{3}$ Master of PSLP Study Program, Universitas Brawijaya \\ Jl. Veteran, Malang City - 65145, Indonesia
}

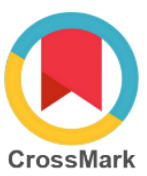

\begin{tabular}{l}
\hline ARTICLE INFO \\
\hline Article history: \\
Received June 06, 2020 \\
Received in revised form June 13, 2020 \\
Accepted July 27, 2020 \\
Available online December 01, 2020
\end{tabular}

Keywords:

Increase in environmental temperature

Utiization of paving blocks

Mixed materials

\section{ABSTRACT}

Global warming increases the overall temperature of the earth's surface and leads to climate change. Therefore, it plays an important impact on human life, especially in the architecture field. This study aims to identify the rise in environmental temperature due to parked cars with running engines and the use of paving blocks as heatreducing material. This is a quantitative research with data collected and measured directly in the field, before being processed and explored of natural and waste materials in the laboratory. The results showed: (1) an increase in environmental temperature of $\pm 34.8^{\circ} \mathrm{C}-39.4^{\circ} \mathrm{C}$, or $5^{\circ} \mathrm{C}$ to $10^{\circ} \mathrm{C}$ due to parked cars with running engines, (2) the use of rectangular and hexagon paving blocks as heat-reducing material. Therefore, the increase in environmental temperature is reduced by the use of paving blocks, which comprises

*Corresponding author: Mohammad Imran Department of Architecture Engineering, STITEK Bina Taruna, Indonesia Email: imransains02ars@gmail.com of basic (cement, sand, and water), natural (grass and fibers), and recycled materials (sawdust and styrofoam).

ORCID: 0000-0002-5794-8121

\section{Introduction}

According to the Intergovernmental Panel on Climate Change (IPCC), the greenhouse effect of human activities has been a significant factor of global warming since the mid-20 $0^{\text {th }}$ century (Suarsana and Wahyuni 2011; Abduh 2017). According to Imran, Wuisang, and Rahmat (2019), overheating in urban areas due to excessive emissions, is called urban heat island (Imran et al. 2019). An increase in the average earth temperature above $20^{\circ} \mathrm{C}$ leads to an unmanageable impact by both humans and nature (Samidjo and Suharso 2017).

Therefore, it is important to carry out all forms of activities, and environmental changes due to temperatures, using appropriate, measurable, and adaptive methods, especially in urban areas (Sangkertadi and Syafriny 2014). An increase in environmental temperature leads to continuous complaints on the rise in skin temperature on the human body (Dede 2019). Therefore, it is important to ensure the thermal comfort aspects of outdoor space (Sazali et al. 2017). Similarly, Purwanto (2019) stated that thermal comfort had become part of human life to interact with the physical environment (Purwanto 2019; Munawaroh and Elbes 2019).

Jefrey Ignatius Kindangen (2016) researched outer space in Manado City trade areas to determine the regions' ability to develop into an open and strategic area, which provides national and international scale needs the patterns and structures of the city (Kindangen 2016). The Manado City functions as a strategic economic and tourism area (Prijadi, Sangkertadi, and Tarore 2014). 
The increase in outdoor heat activity had an impact on the earth and all living things based on the phenomena regarding global warming. Therefore, the research questions are described as follows: (1) how does a rise in environmental temperature affect trading activity in Manado city? (2) how can environmental heat be reduced?

The purpose of this study is to identify the rise in environmental temperature due to parked cars with running engines, and the use of paving blocks as heat-reducing material. This research innovates and contributes to the ideas/concepts for the development of architectural science specifically for thermal comfort material outside space and enables urban communities, to use paving blocks as a heat reduction prototype.

\section{Method}

This is a quantitative research with data collected and measured directly in the field, before being processed and explored of natural and waste materials in the laboratory.

The study was conducted for \pm 2 (two) years: (1) the first year started from March-August 2018 and (2) the second year from March-August 2019.

Data source

a) Primary data were collected from the following:

1 Solar thermal radiation levels taken directly at the point of data retrieval location;

2 Car characteristics include type; color and glass type (transparent or dark);

3 The number of existing cars taken directly at the point of collection;

4 Ground cover material characteristics, shade plant, and function of the data collection area;

5 Characteristics of natural materials and waste used in exploring the development of paving block materials.

b) Secondary data needed including:

1 Daily average temperature of the Manado city;

2 Physical characteristics of the urban areas,

3 Daily average humidity;

4 Data on heat absorption rate (albedo) material;
5 Heat standard data for the trade function area in accordance with the provisions of government and related ministries.

Research instruments

Increase in temperature due to motor vehicle activity is detailed as follows:

a) Measurement and observation area

The measurement and observation area at the Mall parking is divided into 2 and both are 50 meters in front behind the Mall. The measurement and observation area around Manado Town comprises of Pierre Tendean Street at 220 meters and Square 3 parking area of 100 meters.

At the Pierre Tendean Street, vehicles with heavy volumes move slowly, while the tenuous ones are allowed to run fast.

b) Shooting and recording

The shooting was taken at the data collection locations according to their parking conditions, traffic, car characteristics, and the presence of fences, trees or materials, and road cover material such as asphalt and paving blocks. Furthermore, the shooting was also carried out while exploring the material for developing paving blocks in the laboratory.

Environmental heat was measured by identifying solar radiation, the surface temperature of the material, and wind velocity.

Classification and synchronization of data use mahoney tables with the "Matahari" and Microsoft Excel software.

c) Data collection instrument

A total of 9 instruments were used for data collection at the research location, including shooting, recording, processing, and exploring natural materials and waste carried out at the laboratory. Details of the instruments used are in accordance with table 1 .

Table 1. List of instruments used

\begin{tabular}{llll} 
No. & Parameter & Total & Tool's name \\
\hline 1 & $\begin{array}{l}\text { Environmental } \\
\text { temperature }\end{array}$ & 8 & $\begin{array}{l}\text { Outdoor Digital } \\
\text { Thermometer }\end{array}$ \\
\hline 2 & $\begin{array}{l}\text { Material Surface } \\
\text { Temperature (solid) }\end{array}$ & 4 & $\begin{array}{l}\text { Thermometer } \\
\text { Infra Red }\end{array}$ \\
\hline 3 & $\begin{array}{l}\text { Physical area wide of } \\
\text { the data collection } \\
\text { location }\end{array}$ & 4 & Meter \\
\hline 4 & $\begin{array}{l}\text { Visual } \\
\text { Documentation }\end{array}$ & 4 & camera \\
\hline 5 & Wind velocity & 4 & Anemometer \\
\hline 6 & $\begin{array}{l}\text { Record measurement } \\
\text { and observation data }\end{array}$ & 4 & Stationary \\
\hline
\end{tabular}




\begin{tabular}{llll}
\hline No. & Parameter & Total & Tool's name \\
\hline 7 & Anticipate rain and & 4 & Umbrella \\
heat & $\begin{array}{l}\text { Adjust the shape and } \\
\text { size of paving block }\end{array}$ & $\begin{array}{l}\text { (1 rectangular } \\
\text { shape and } \\
\text { 1 hexagon } \\
\text { shape) }\end{array}$ & Molding \\
\hline
\end{tabular}

\begin{tabular}{llll}
\hline No. & Parameter & Total & Tool's name \\
\hline 9 & Compact material & 1 & Printing \\
& mix and print paving & & Equipment with \\
& blocks & Vibrator and \\
& & Drop Gravity \\
& & System \\
\hline
\end{tabular}

\section{Research scheme}

The principle of the research scheme is describer as follows (figure 1):

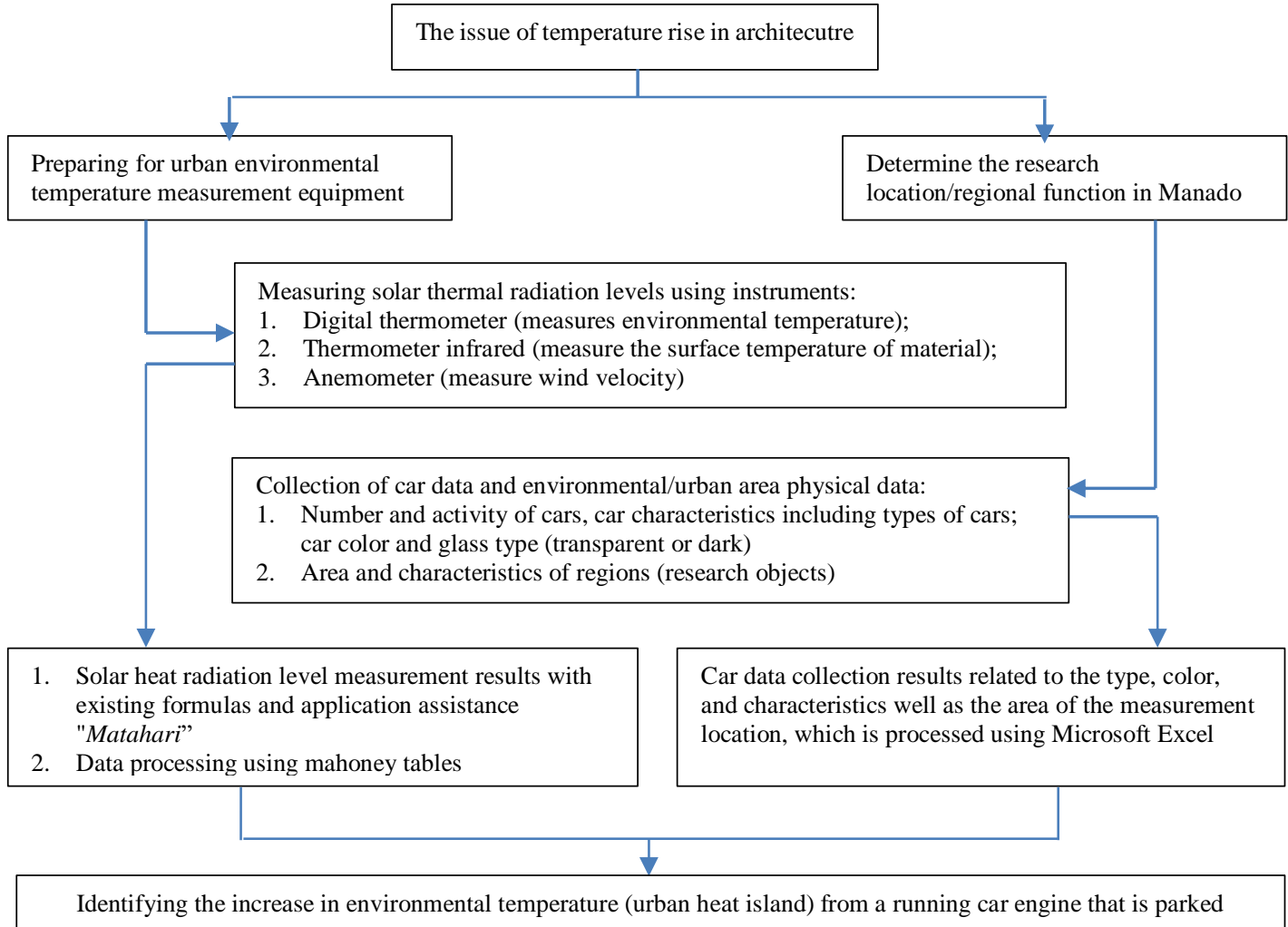

\begin{tabular}{|c|c|}
\hline & First-year (2018) \\
\hline 1 & \\
\hline $\begin{array}{l}\text { A natural material that can be processed into heat } \\
\text { reducing material: } \\
\text { 1. Wood; } 2 \text {. Sand; } 3 \text {. Brick; } 4 \text {. Concrete brick; } 5 \text {. } \\
\text { Marble stone and natural stone; } 6 \text {. Palm fiber and } \\
\text { thatch }\end{array}$ & $\begin{array}{l}\text { Waste Materials become heat Reducing Materials: } \\
\text { 1. Recycling materials (waste, garbage, pulp, } \\
\text { packaging materials, car tires, sawdust, glass } \\
\text { pieces) } \\
\text { 2. The material undergoes a simple transformation: } \\
\text { clay tile, brick, block, metal, and glass }\end{array}$ \\
\hline & \\
\hline
\end{tabular}

Second-year (2019)

Figure 1. Research Scheme 


\section{Data collection}

Measurement and collection of data on the air heat level in the central area of the Manado City trade services are as follows:

1. In July and August 2018, due to the increase in solar radiation to the earth's surface.

2. Data were collected for 10 (ten) days in a month with the weather conditions, adjusted in the following dates/days:

a. July 2018: on the 5th (Thursday), 6 (Friday), 8 (Sunday), 9 (Monday), 16 (Monday), 17 (Tuesday), 27 (Friday), 28 (Saturday), 29 (Sunday) and 30 (Monday).

b. August 2018: On the 2nd (Thursday), 6 (Monday), 8 (Wednesday), 9 (Thursday), 18 (Saturday), 19 (Sunday), 24 (Friday), 27 (Monday), 29 (Wednesday) and 30 (Thursday).

3. The data collection of air temperature is adjusted to the position of the sun and the heat level in a day at (1) 08.00 am, (2) 09:30 am, (3) $11.00 \mathrm{am}$, (4) $1: 00 \mathrm{pm}$, (5) 2:30 pm and (6) 4:00 pm.

4. Dates that with collection points were carried out in 4 (four) places as follows:

a. The parking Area in front of the mall is 50 $\mathrm{m} \times 12 \mathrm{~m}$. Placement of the measuring points is $\mathrm{T} 1$ to $\mathrm{T} 10$ and spaced 10 meters from each other, as shown in figure 2 . The area is shaded blue, and data is collected using a measuring instrument such as a digital outdoor thermometer, anemometer, and infrared, as shown in figure 3.

b. The parking area behind the Mall is $50 \mathrm{~m}$ x $12 \mathrm{~m}$, with the measuring points placed from T1 to T10 and spaced 10 meters, as shown in figure 4 . The area is shaded blue, and data is collected using a measuring instrument such as a digital outdoor thermometer, anemometer, and infrared, as shown in figure 5 .

c. The area on Pierre Tendean street is $220 \mathrm{~m}$ with the measuring points placed from $\mathrm{T} 1$ to T22 and spaced 10 meters, as shown in figure 6 . The area is shaded blue, and data is collected using a measuring instrument such as digital outdoor thermometer, anemometer, and infrared, as shown in figure 7.

d. Manado Town Square 3 parking area is $1000 \mathrm{~m} \times 12 \mathrm{~m}$ with the measuring points placed from $\mathrm{T} 1$ to $\mathrm{T} 10$ and spaced 10 meters, as shown in figure 8 . The area is shaded blue, and data is collected using a measuring instrument such as a digital outdoor thermometer, anemometer, and infrared as shown in figure 9 .

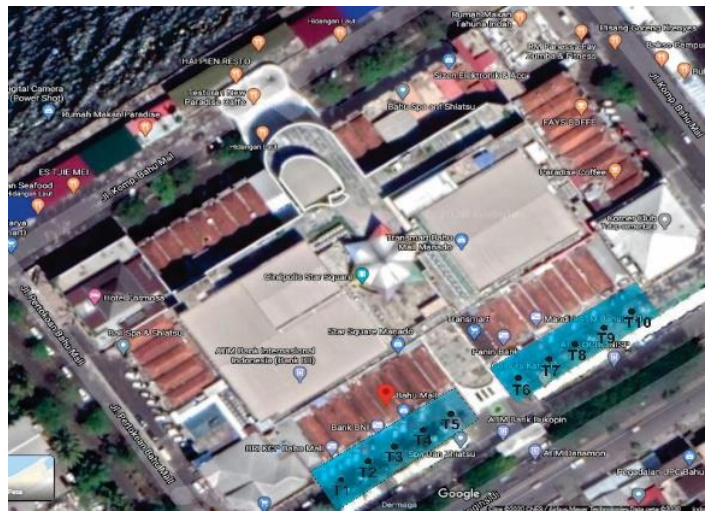

Figure 2. Parking area in front of the mall

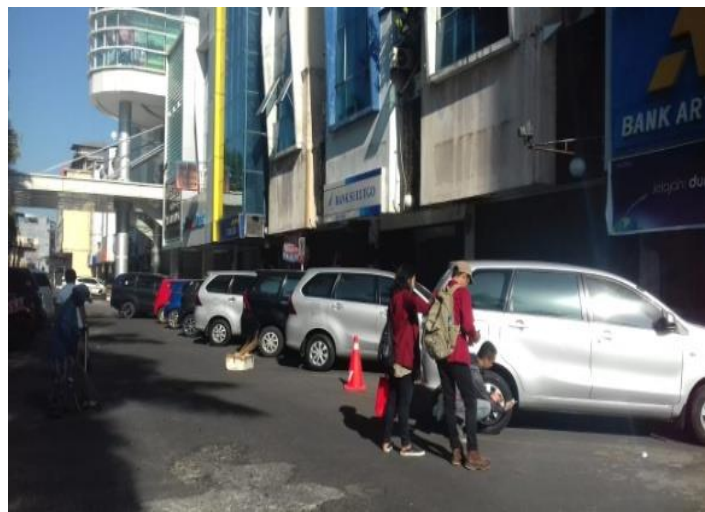

Figure 3. Collecting data in the parking area in front of the mall

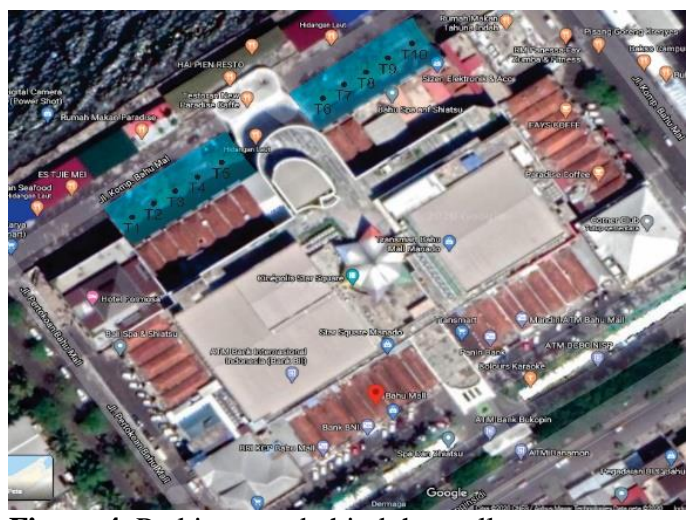

Figure 4. Parking area behind the mall 


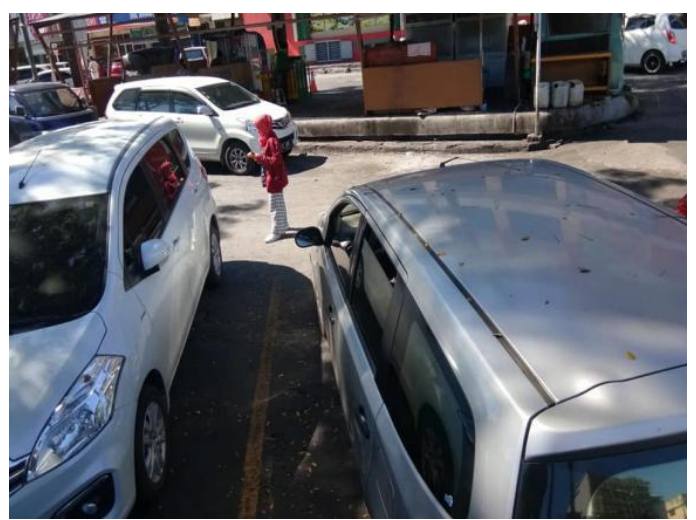

Figure 5. Data collection in the parking area behind the mall

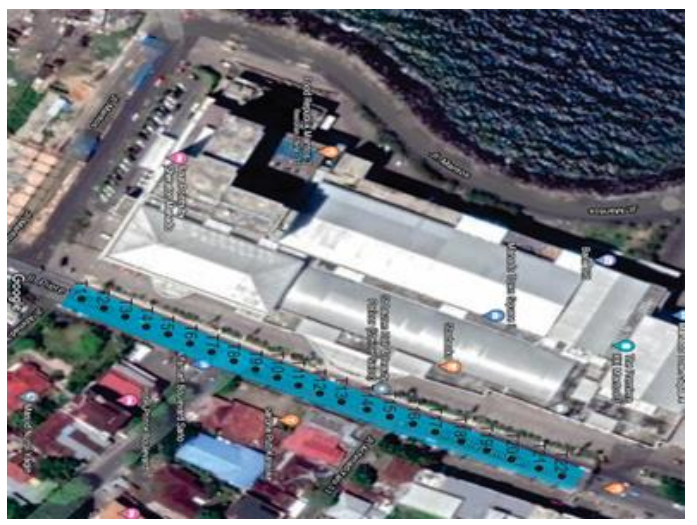

Figure 6. Area along Pierre Tendean Street (int front of Manado Town Square 3)

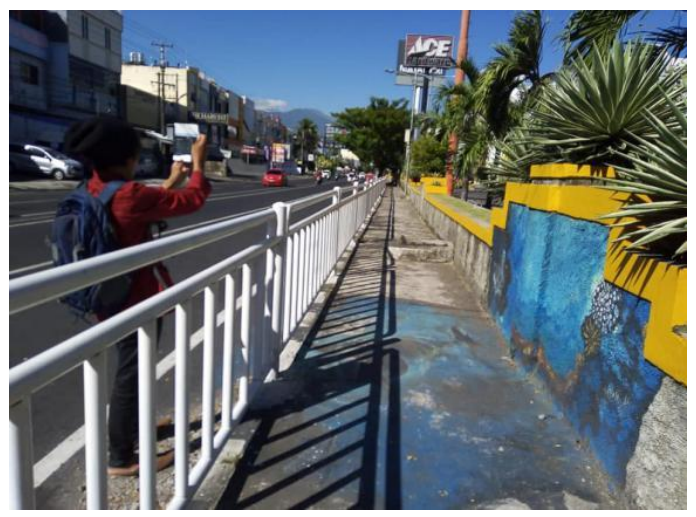

Figure 7. Data collection in the parking area on Pierre Tendean Street

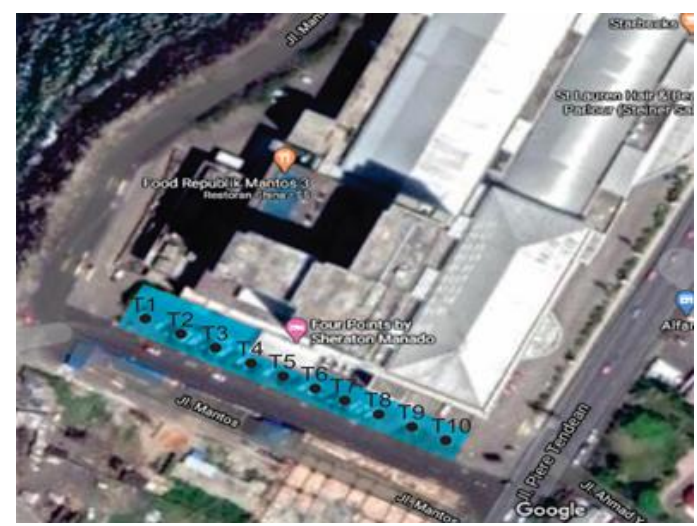

Figure 8. Manado Town Square parking area 3

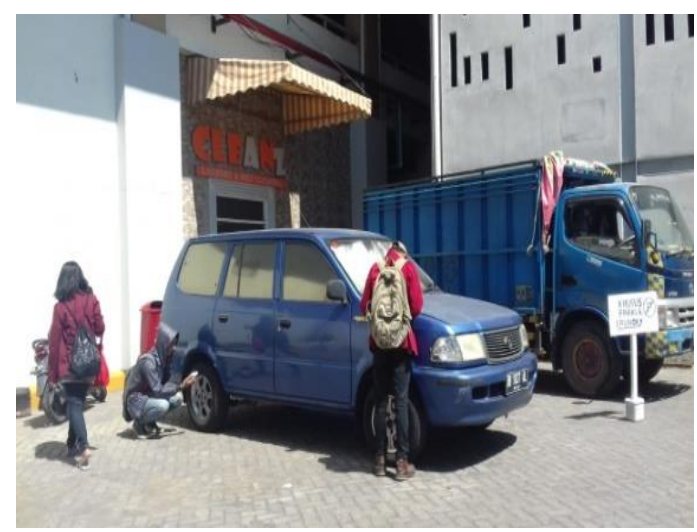

Figure 9. Data collection in the Manado Town Square parking area 3

\section{Result and discussion}

\section{The first-year findings}

The data processing results showed several measuring samples with an average maximum value of 4 (four) as follows:

1. Parking area in front of the mall

The air temperature in the parking area of the front of the mall is $36.10^{\circ} \mathrm{C}$.

2. Parking area behind the mall

The air temperature of the parking area behind the Mall is $34.80^{\circ} \mathrm{C}$.

3. The areas along Pierre Tendean Street (in front of Manado Town Square 3)

Air temperature at Pierre Tendean Street area is $36.40^{\circ} \mathrm{C}$.

4. Manado Town Square parking area 3

The air temperature in the Manado Town Square 3 parking area is $39.40^{\circ} \mathrm{C}$. 
The data processing result recapitulation for the maximum air temperature at the four points is shown in table 2 .

Table 2. Heat level recapitulation

\begin{tabular}{ll}
\hline $\begin{array}{l}\text { Average } \\
\text { temperature }\left({ }^{\circ} \mathbf{C}\right)\end{array}$ & Research sites \\
\hline 36,1 & Parking area in front of the mall \\
\hline 34,8 & Parking area behind the mall \\
\hline 36,4 & $\begin{array}{l}\text { Piere Tendean Street (in front of } \\
\text { Manado Town Square 3) }\end{array}$ \\
\hline 39,4 & $\begin{array}{l}\text { Parking area in front of Manado Town } \\
\text { Square 3 }\end{array}$ \\
\hline
\end{tabular}

Discussion

Data were analyzed using the Mahoney table, which is combined with the average air temperature from January to September 2018. Manado's highest air temperature occurs in August, in which it can reach $31.9^{\circ} \mathrm{C}$, while the lowest was in January at $26.6^{\circ} \mathrm{C}$. The highest and lowest temperature and humidity data are shown in figure 10 and table 3.

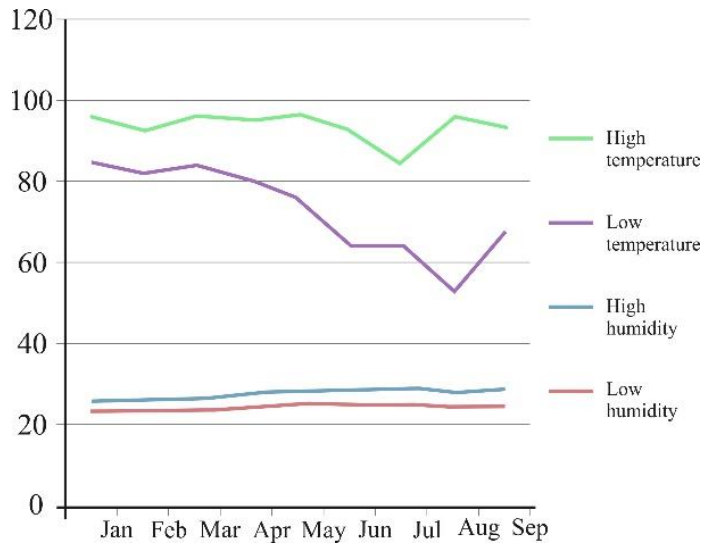

Figure 10. High and low temperature and humidity

Table 3. Average temperature and humidity

\begin{tabular}{lll}
\hline Month & Temperature $\left({ }^{\circ} \mathbf{C}\right)$ & Humidiy $(\%)$ \\
\hline January & 26.6 & 89.5 \\
\hline February & 28.8 & 87.1 \\
\hline March & 28.5 & 90.2 \\
\hline April & 29.3 & 87.9 \\
\hline May & 29.6 & 85.3 \\
\hline June & 29.9 & 82.7 \\
\hline July & 30.3 & 75.6 \\
\hline August & 31.9 & 71.6 \\
\hline September & 29.6 & 83 \\
\hline
\end{tabular}

Based on data processing at the four collection points, the environmental temperature increased between $5^{\circ} \mathrm{C}$ to $10^{\circ} \mathrm{C}$. This is due to the number of cars and activities in the Mall area, along with
Piere Tendean street and the Manado Town Square 3.

\section{The second-year findings}

It is necessary to use a material that reduces heat, such as solid objects (Munir et al. 2018). Environmental architecture contributes to the utilization of natural materials that are processed from waste products to reduce heat. Mediastics in Imran, Wuisang, and Rahmat (2019), stated that sustainability and environmentally friendly factors are the main heat-reducing materials which are conducted in urban areas through the following considerations (Imran et al. 2019):

1. Benchmarks (landscape) especially green open spaces in urban areas use city parks to reduce heat (Mulyandari and HS. 2011).

2. Increase the types of plants and trees to reduce the quantity of solar radiation that falls to the earth surface and the ground (Mediastika 2013).

3. It is better to use a soil layer with grass material, garden, and brick to reduce soil pavement (Sangkertadi and Syafriny 2014).

According to Mediastika (2013), Indonesia is a tropical country rich in natural diversity (Mediastika 2013). A variety of natural materials are used to reduce heat, namely: (1) wood, (2) sand, (3) bricks, (4) building block, (5) marble and natural stones, (6) palm fiber, and thatch. Meanwhile, according to Frick (2007), natural materials such as stone, wood, bamboo, and clay do not contain substances that interfere with health (Frick and Mulyani 2006). Some artificial materials also function as heat-absorbing materials that are safe for health, such as (1) Recycling materials: waste, garbage, pulp, packaging materials, car tires, sawdust, pieces of glass. (2) Simple transformations: red stone, tiled clay, brick, con-block, metal, glass, and cement. Land and soft materials are used to develop contextual concepts with nature, which is central to human synergy with the environment (Srinaga and Prakoso 2019).

The energy performance of a material used to store heat is determined by simply knowing the insulation value of a material. This is because the entire surface area is not completely filled with insulation materials (Purwanto 2019). Therefore, when waste materials are explored, the original characteristics and properties produce heat, 
reducing material mix, which is relatively large, as shown in table 4.

Table 4. Heat absorbance numbers

\begin{tabular}{ll}
\hline Material & Surface absorption numbers (aw) \\
\hline Thick concrete & 0,91 \\
\hline Redbrick & 0,89 \\
\hline Bitumen sheet & 0,88 \\
\hline Slatestone & 0,87 \\
\hline Lightweight concrete & 0,86 \\
\hline Asphalt trail & 0,82 \\
\hline Smoth surface wood & 0,87 \\
\hline Exposed concrete & 0,61 \\
\hline White tile & 0,58 \\
\hline Dark yellow brick & 0,56 \\
\hline White roof & 0,50 \\
\hline Aluminum paint & 0,40 \\
\hline Gravel & 0,29 \\
\hline White zinc & 0,26 \\
\hline White glazed brick & 0,25 \\
\hline Shiny aluminum sheet & 0,12 \\
\hline Sumber: (Satwiko 2008$)$
\end{tabular}

The materials used as a mixture in the manufacture of paving blocks include grass, fibers, sawdust, and styrofoam. The use of natural material such as wood and sawdust in a mixture of cement and sand is absorbed on the surface of the mineral/concrete particles. Therefore, it provides additional bonding strength between particles due to the adhesion and dispersion properties and inhibits the diffusion of water in the material due to its hydrophobic nature (Saifuddin, Edison, and Fahmi 2013). Furthermore, natural materials mixed with concrete, such as coconut fiber, can also be used as reinforcing concrete because it has lighter density than sand (Prahara, Liong, and Rachmansyah 2015). Furthermore, the mixture of sand and fibers also meet the standard of nonstructural or construction compressive strength. Natural fibers such as sawdust, grass, and fibers reduce energy consumption and air pollution (Prastyatama and Maurina 2018). The heatreducing material, which functions as a water provider, is a type of paving block that is part of the landscape's hard materials acting as a footpath for pedestrians, and parking areas (Prasetyo, Yuliarso, and Suparno 2019).

Furthermore, mixing materials to manufacture paving blocks as a heat-reducing material is carried out as follows:

1. Material mixing process

The composition of the mixture is $15 \%$ grass, $15 \%$ palm fiber, $15 \%$ wood powder, $15 \%$ streform, $15 \%$ sand, $20 \%$ cement and $5 \%$ water.
Dough mixing need to be evenly distributed manually as shown in figure 11 .

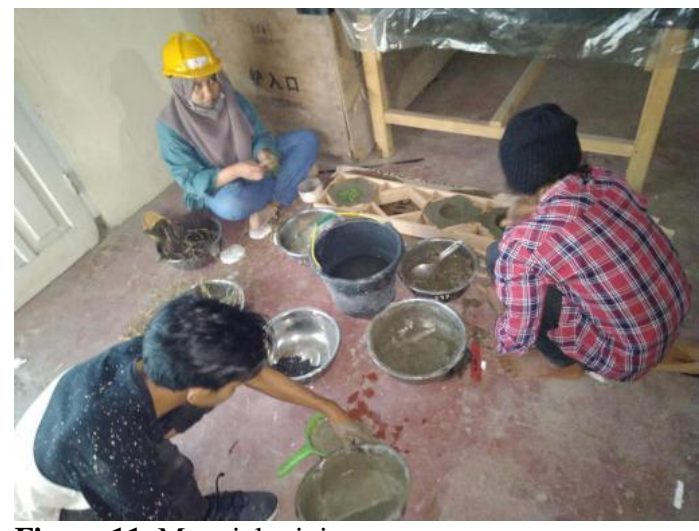

Figure 11. Material mixing process

2. Manual paving block molding equipment

The simplest paving block used as printing tool are manually made of wood. The mixed dough is put into a closed molding, and beaten for condensation. This process is shown in figure 12 .

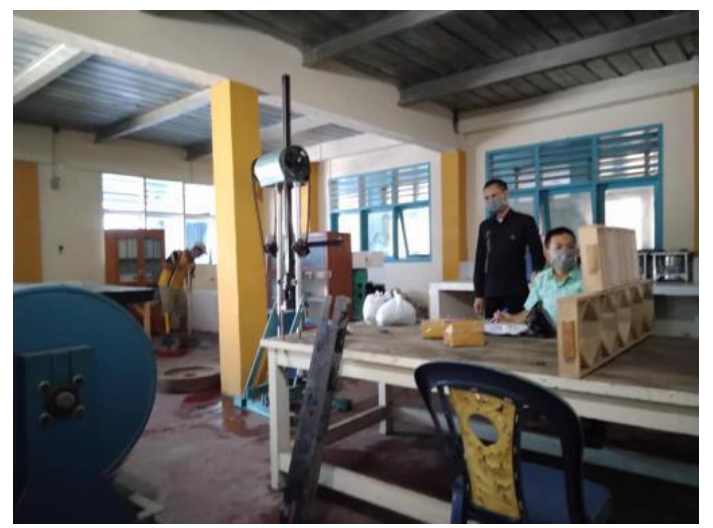

Figure 12. Molding tool

\section{Molding process}

The molding process is carried out on this dough in order to get optimum quality and strength of the paving blocks. This process is shown in figure 13 . 


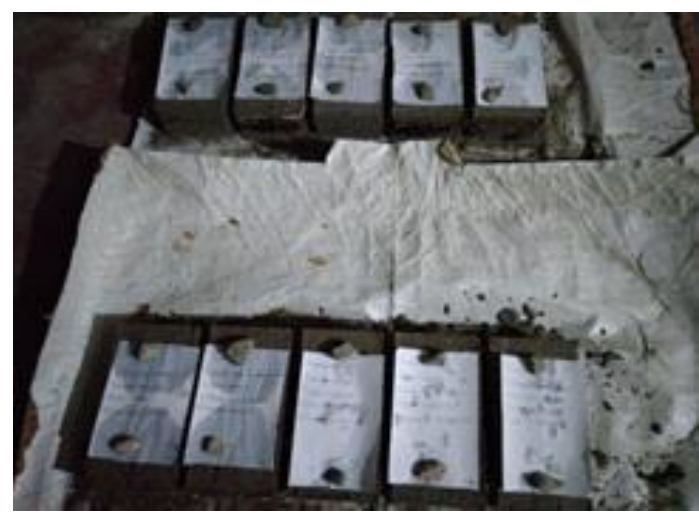

Figure 13. Molding process

4. Molding tool with vibrator and drop gravity system

In addition to manual molding tools, this study also used a vibrator and drop gravity molding machine. The mixture is put in molding and compacted by the force of gravity. Paving blocks have high quality with a power level of \pm 160 $\mathrm{kg} / \mathrm{cm}, 2-180 \mathrm{~kg} / \mathrm{cm}^{2}$.

5. Drying process

The next step is the drying which is placed and arranged in the Building Materials Technology and Physics Laboratory, Department of Architecture, Faculty of Engineering, Sam Ratulangi University and Structure and Materials Laboratory, Department of Civil Engineering, STITEK Bina Taruna as shown in figure 14.

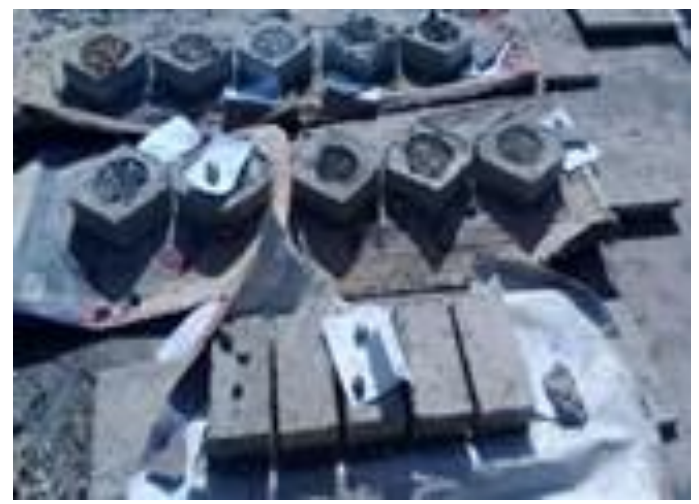

Figure 14. Drying process

\section{Discussion}

This research developed 2 (two) types of heat reducing material products, as follows:

1. Rectangular paving blocks have characteristics:

(a) More solid; (b) It has a compressive strength of $14.94 \mathrm{MPa}$ which is equivalent to $180 \mathrm{~kg} / \mathrm{cm}^{2}$;

(c) The heat reducing material contained grass, fibers, sawdust and styrofoam. This material are evenly mixed and compacted in each part to obtain paving blocks with a size of $21 \mathrm{~cm}$ x $10.5 \mathrm{~cm}$ x $6 \mathrm{~cm}$;

(d) Static form;

(e) The level of heat reduction $\pm 0.5^{\circ} \mathrm{C}$ $1.5^{\circ} \mathrm{C} /$ square meter (44 pieces).

2. Hexagon paving blocks have characteristics:

(a) Solid;

(b) It has a compressive strength of $13.28 \mathrm{MPa}$ which is equivalent to $160 \mathrm{~kg} / \mathrm{cm}^{2}$;

(c) The heat reducing material contained grass, fibers, sawdust, and styrofoam. This material is mixed evenly and evenly compacted in each section with a size of 21 $\mathrm{cm} \times 21 \mathrm{~cm} \times 6 \mathrm{~cm}$;

(d) Dynamic form;

(e) The level of heat reduction $\pm 0.5 \mathrm{oC}$ $1.8^{\circ} \mathrm{C} /$ square meter (25 pieces).

\section{Conclusion}

Based on the results of this study, it can be concluded that: (1) the maximum environmental temperature is in the Manado Town Square 3 parking area, which is $39.4 \mathrm{oC}$ due to the large number of motorized vehicles parked with their engine running. Furthermore, there are no trees or shade in the parking area, which is directly adjacent to the Piere Tendean shaft road, thereby, leading to high average ambient temperatures. (2) the increase in environmental temperature tends to be reduced by the use of paving blocks, such as sand, water, cement, grass, fibers, sawdust, and styrofoam. The paving blocks are developed in the rectangular and hexagon forms. The placement of this material prototype in open space/border area effectively reduces the impact of global warming (urban heat island).

\section{Acknowledgment}

The authors are grateful to all those that helped during the research, including:

1. Director General of Community Research and Development, Ministry of Research Technology, and Higher Education to fund the 
PKPT skim research for the 2018-2019 budget year.

2. Prof. Dr. Ir. H. Sangkertadi, DEA. as Vice Rector for Collaboration and Infrastructure at Sam Ratulangi University, Manado, who spent his time and energy writing this article.

3. Dr. Judy Obet Waani, ST., MT. as Vice Dean for Academic and Collaboration at the Faculty of Engineering, Sam Ratulangi University, Manado, who provided the opportunity to use the Building Materials Technology and Physics Laboratory, Department of Architecture.

4. Dr. H. Azis Rachman, ST., MM. as Chairperson of STITEK Bina Taruna who provided the opportunity to use the Laboratory of Structures and Materials, Civil Engineering Study Program.

\section{References}

Abduh, M. Natsir. 2017. 'Teknologi Green Pada Bangunan Berkelanjutan'. In Seminar Ilmiah Nasional Teknik Sipil Universitas Bosowa, SINALTSUB-I, 1-17. Makassar: Teknik Sipil Universitas Bosowa.

https://tekniksipilunibos.ac.id/wpcontent/uploads/2018/04/2017_PROSIDING _M.NATSIR_archive.pdf.

Dede, Petrus Jhon Alfred Depa. 2019. 'Respon Pengunjung Dan Pedagang Terhadap Kondisi Lingkungan Termal (Suhu Udara) Di Pasar Wolowona Kota Ende'. TEKNOSIAR 13 (1): $1-6$. https://doi.org/10.37478/teknosiar.v13i1.226.

Frick, Heinz, and Tri Hesti Mulyani. 2006. Arsitektur Ekologis: Konsep Arsitektur Ekologis Pada Iklim Tropis, Penghijauan Dan Kota Ekologis, Serta Energi Terbarukan. Yogyakarta: Kanisius.

Imran, Mohammad, Sangkertadi, Cynthia E. V. Wuisang, and Abdul Rahmat. 2019. 'Thermal Analisys of the Increase in Ambient Temperature Due to Motor Vehicle Activities'. International Journal of Engineering and Advanced Technology 9 (2): 751-54. https://doi.org/10.35940/ijeat.B2864.129219.

Kindangen, Jefrey Ignatius. 2016. 'Cooling Performance of Spraying Water Automatically on The Roof Surface for Thermal Comfort in Buildings in Manado'. In
The 11th International Symposium on Architectural Interchanges in Asia (11th ISAIA). Japan: Tohoku University, Sendai, Miyagi, Japan.

Mediastika, Christina E. 2013. Hemat Energi Dan Lestari Lingkungan Melalui Bangunan. Yogyakarta: Andi.

Mulyandari, Hestin, and Oktaviani HS. 2011. Pengantar Arsitektur Kota. Yogyakarta: Andi.

Munawaroh, Ai Siti, and Rivena Elbes. 2019. 'Penilaian Kenyamanan Termal Pada Bangunan Perpustakaan Universitas Bandar Lampung'. ARTEKS: Jurnal Teknik Arsitektur $\quad 4 \quad$ (1): 85-98. https://doi.org/10.30822/arteks.v4i1.83.

Munir, E, R S M Harefa, N Priyani, and D Suryanto. 2018. 'Plastic Degrading Fungi Trichoderma Viride and Aspergillus Nomius Isolated from Local Landfill Soil in Medan'.

IOP Conference Series: Earth and Environmental Science 126 (March): 012145. https://doi.org/10.1088/17551315/126/1/012145.

Prahara, Eduardi, Gouw Tjie Liong, and Rachmansyah Rachmansyah. 2015. 'Analisa Pengaruh Penggunaan Serat Serabut Kelapa Dalam Presentase Tertentu Pada Beton Mutu Tinggi'. ComTech: Computer, Mathematics and Engineering Applications 6 (2): 208. https://doi.org/10.21512/comtech.v6i2.2265.

Prasetyo, Iqbal, Hari Yuliarso, and Suparno. 2019. 'Penerapan Teori Arsitektur Hijau Pada Pengolahan Tapak Terminal Bus Tipe A Di Kulon Pogo'. Senthong: Jurnal Ilmiah Mahasiswa Arsitektur 2 (1): 247-56. https://jurnal.ft.uns.ac.id/index.php/senthong/ article/view/847/446.

Prastyatama, Budianastas, and Anastasia Maurina. 2018. 'Kinerja Struktural Interlocking Compressed Earth Block (ICEB) Dengan Serta Ijuk Sebagai Stabilisator'. ARTEKS : Jurnal Teknik Arsitektur 3 (1): 2736. https://doi.org/10.30822/arteks.v3i1.51.

Prijadi, Rachmat, Sangkertadi, and Raymond D. Ch. Tarore. 2014. 'Pengaruh Permukaan Jalur Pedestrian Terhadap Kepuasan Dan Kenyamanan Pejalan Kaki Di Pusat Kota Manado'. MEDIA MATRASAIN 11 (1): 4354.

https://ejournal.unsrat.ac.id/index.php/jmm/ar ticle/view/4984/4500.

Purwanto, Leonardus Murialdo Fransiskus. 2019. 'Simulasi Transfer Panas Pada Dinding Dengan Software Therm 7.7'. ARTEKS: 
Jurnal Teknik Arsitektur 4 (1): 111-16. https://doi.org/10.30822/arteks.v4i1.215.

Saifuddin, Muhammad Ikhsan, Bambang Edison, and Khairul Fahmi. 2013. 'Pengaruh Penambahan Campuran Serbuk Kayu Terhadap Kuat Tekan Beton'. Jurnal Mahasiswa Teknik 1 (1). https://ejournal.upp.ac.id/index.php/mhsteknik/article /view/201.

Samidjo, Jacobus, and Yohanes Suharso. 2017. 'Memahami Pemanasan Global Dan Perubahan Iklim'. Majalah Ilmiah Pawiyatan 24 (2): $1-10$.

Sangkertadi, S., and R. Syafriny. 2014. 'New Equation for Estimating Outdoor Thermal Comfort in Humid-Tropical Environment.' European Journal of Sustainable Development 3 (4): 43-52. https://doi.org/10.14207/ejsd.2014.v3n4p43.

Satwiko, Prasasto. 2008. Fisika Bangunan. Yogyakarta: Andi.

Sazali, Munawir, Laili Indana Zulpa, Ilham Kusuma, and Edwin Pane. 2017. 'Peran
Kanopi Pohon Sebagai Ecosystem Services Berbasis Iklim Mikro Terhadap Kenyamanan Pengendara Motor Di Selaparang Kota Mataram'. In Seminar Nasional MIPA 2017, 22-27. Mataram: Universitas Nahdlatul Wathan Mataram.

Srinaga, Felia, and Susinety Prakoso. 2019. 'Perancangan Lansekap Taman Dan Penempatan Rumah Doa'. Jurnal Sinergitas PKM Dan CSR 3 (2): 1-15. https://ojs.uph.edu/index.php/JSPC/article/vie w/1685/PDF.

Suarsana, Made, and Putu Sri Wahyuni. 2011. 'Global Warming: Ancaman Nyata Sektor Pertanian Dan Upaya Mengatasi Kadar Co2 Atmosfer'. WIDYATECH Jurnal Sains Dan Teknologi $11 \quad$ (1): $\quad 31-46$. https://jurnalwidyatech.files.wordpress.com/2 012/02/made-suarsana-dan-putu-sriwahyuni.pdf. 